\title{
Growth and development of bell pepper crop irrigated with magnetically-treated water
}

\section{Marcelo Zolin Lorenzoni ${ }^{1}$, Roberto Rezende ${ }^{2}$, Álvaro Henrique Cândido de Souza², Cássio de Castro Seron ${ }^{3}$, Antônio Carlos Andrade Gonçalves ${ }^{2}$, Reni Saath ${ }^{2}$}

${ }^{1}$ Instituto Federal Goiano, Campus Posse, Posse, Goiás, Brasil. E-mail: marcelo.lorenzoni@ifgoiano.edu.br

${ }^{2}$ Universidade Estadual de Maringá, Campus de Maringá, Maringá, Paraná, Brasil. E-mail: rrezende@uem.br, alvarohcs@hotmail.com, acagoncalves@uem.br, rsaath@uem.br

${ }^{3}$ Universidade Estadual de Mato Grosso do Sul, Unidade Universitária de Cassilândia, Cassilândia, Mato Grosso do Sul, Brasil. E-mail: cassio.seron@uems.br

Received: 14/12/2019; Accepted: 05/05/2020.

\section{ABSTRACT}

This study aimed to evaluate the benefits of irrigation with magnetically-treated water and replacement depths based on ETc, in plant growth and development of bell pepper grown in a protected environment in two cultivation seasons. The experiment was carried out in a protected environment, in the Centro Técnico de Irrigação (CTI), at Universidade Estadual de Maringá (UEM), in Maringá - PR. Two experiments were performed: summer (2017-2018) and winter-spring (2018). The experimental design adopted was randomized blocks in factorial scheme $3 \times 2$ (six treatments) with four replications in the summer season and $2 \times 2$ (four treatments) with six replications in the winterspring season. The first factor consisted of water replacement depths $(50,75$ and $100 \%$ of the evapotranspiration of culture (ETc) in the summer season, and 75 and 100\% ETc in the winter-spring season. The second factor was the application of water with and without magnetic treatment. Characteristics of growth (plant height, stem diameter, leaf area, and dry matter of stem, leaf, total, and root) and development (first flower and first fruit) were evaluated. Results showed that there was no significant interaction between the factors for the summer season. There were only isolated effects of replacement depths, and the $100 \%$ ETc had the highest values for the growth variables, independent of water treatment. The application of magnetically-treated water provided higher accumulation of dry matter (stem, total, and root) when irrigated with $75 \% \mathrm{ETc}$ for the winter-spring season.

Keywords: Magnetic field, Capsicum annuит L., magnetism, agronomic parameters.

\section{Crescimento e desenvolvimento da cultura do pimentão irrigada com água tratada magneticamente}

\section{RESUMO}

O presente trabalho teve como objetivo avaliar o crescimento e o desenvolvimento da cultura do pimentão submetido a diferentes lâminas de irrigação e aplicação de água com e sem tratamento magnético em dois ciclos de cultivo. O experimento foi conduzido em ambiente protegido localizado no Centro Técnico de Irrigação (CTI), pertencente à Universidade Estadual de Maringá (UEM), município de Maringá - PR. Dois experimentos foram realizados, o primeiro no período de verão (2017-2018) e o segundo no inverno e primavera (2018). O delineamento experimental foi em blocos ao acaso em esquema fatorial $3 \times 2$ ( 6 tratamentos) com 4 repetições no ciclo de verão e 2 × 2 ( 4 tratamentos) com 6 repetições no ciclo de inverno-primavera. O primeiro fator consistiu em três níveis de reposição da irrigação $(50,75$ e $100 \%$ da evapotranspiração da cultura (ETc)) no ciclo de verão e dois níveis de reposição da irrigação ( 75 e 100\% da ETc) no ciclo inverno-primavera, e o segundo fator consistiu na aplicação da água com e sem tratamento magnético. Foram avaliadas as características de crescimento (altura; diâmetro do caule; área foliar; massa seca de caule, folha e total e massa seca de raiz) e as características de desenvolvimento (primeira flor e primeiro fruto). Os resultados demostraram que não houve interação significativa entre os fatores para o ciclo de verão, apenas efeito isolado para os níveis de reposição, sendo a lâmina de $100 \%$ da ETc a que apresentou maiores valores para as variáveis de crescimento, independente do tratamento da água. A aplicação de água com tratamento magnético proporcionou maior acúmulo de biomassa seca (caule, total e raiz) quando irrigada com $75 \%$ da ETc no ciclo de inverno-primavera.

Palavras-chave: campo magnético, Capsicum аппиит L., magnetismo, parâmetros agronômicos. 


\section{Introduction}

Bell pepper (Capsicum annuum L.) is a fruit-type belonging to the Solanaceae family, as well as tomato, potato, eggplant, pepper, and scarlet eggplant. It is one of the most appreciated vegetables in Brazil, standing out among the ten of the most economical and social importance (Lorenzoni et al., 2016).

Due to the great prominence of this product in the market, bell pepper producers are increasingly investing in production-friendly technologies, like growing in a protected environment, hybrid seeds, efficient irrigation systems, and fertilizer application via fertigation. However, in agricultural science, there is no interest only in the use of the technologies mentioned, but also those of low cost and generally underestimated, such as the use of magnets for magnetic water treatment (Mahmood and Usman, 2014).

According to Mahmood and Usman (2014), magnetic field-treated irrigation water may be a promising technique for agriculture, but research in a variety of cultures is required. Authors reveal that constant use of magnetic water treatment can lead to increased nutrient absorption and biomass production in different crops (Mahmood and Usman, 2014; Maheshwari and Grewal, 2009).

According to Ali et al. (2014), water characteristics can be changed with magnetic treatment and cause changes in plant properties, growth, and yield. Putti et al. (2013) investigating the application of water with magnetic treatment in the initial development of lettuce, in the municipality of Botucatu-SP, found a significant increase in root length and dry matter of root and shoot when irrigated with magnetically-treated water.

Surendran et al. (2016) found significant differences in all treatments that received magnetically-treated water in the eggplant; the magnetic treatment of irrigation water increased plant height, number of leaves, and leaf area. Yusuf and Ogunlela (2017) used the same volume of water with and without magnetic treatment to irrigate tomato plants and observed faster growth when irrigated with magnetically-treated water. According to Sayed (2014), studies involving the application of this technology in agriculture are limited, as it involves a series of experimental conditions.

This study aimed to evaluate the benefits of irrigation with magnetically-treated water and replacement depths based on ETc, in plant growth and development of bell pepper grown in a protected environment in two cultivation seasons.

\section{Material and Methods}

The research was developed in two cultivation seasons. In summer (from November 20, 2017, to March 19, 2018) with a 120-day cycle and winter-spring (from June 15, 2018, to November 15, 2018) with a 150-day cycle. The longer cycle in the winter-spring season is because the temperatures caused a delay in the development of plants concerning the summer season.

The two experiments were carried out in a protected environment (30 m long, $7 \mathrm{~m}$ wide and $3.5 \mathrm{~m}$ height) with arch ceiling coated with polyethylene film (150 $\mu \mathrm{m})$ and sides with an anti-aphid screen, in the Centro Técnico de Irrigação (CTI) from Universidade Estadual de Maringá (UEM), in Maringá, Paraná (23⒉ '57' S; $51^{\circ} 57^{\prime} 08^{\prime}$ ' W; altitude of $542 \mathrm{~m}$ ).

According to Köppen classification, the region's climate is Cfa (humid mesothermal), with summer rains and dry winter (Alvares et al., 2013). Within the protected environment, a climatological station has been set up capable of recording climate data through a data acquisition system (datalogger). The Campbell automatic weather station has sensors for temperature, relative humidity, solar radiation, and wind speed and direction, which collects and records data every 2 seconds and makes the average in 30-minute intervals.

For both experiments, a randomized block design in a factorial scheme was used. The first factor consisting of the water replacement depth based on the crop evapotranspiration (ETc), and the second factor was the application of irrigation water with and without magnetic treatment.

For the experiment carried out in the summer season, a $3 \times 2$ factorial scheme was used, totaling six treatments with four replications. In the winter-spring season, a 2 x 2 factorial scheme was used, totaling four treatments with six replications. In the summer experiment, three water replacement depths based on crop evapotranspiration $(50 \%, 75 \%$, and $100 \%$ of ETc) were evaluated. In the winter-spring experiment, two water replacement depths ( $75 \%$ and $100 \%$ of ETc) were evaluated.

For the winter-spring season, it was decided not to apply the $50 \%$ ETc replacement depth due to the drought stress caused to the bell pepper, resulting in low growth and crop yield when compared to 75 and $100 \%$ ETc replacement depths.

The soil of the experimental area is classified as Nitossolo Vermelho distroférrico (Embrapa, 2013) or Oxisol (Soil Survey Staff, 2014), and their chemical characteristics in the $0-10 \mathrm{~cm}$ soil layer are shown in Table 1.

Bell pepper seedlings were produced in polyethylene trays containing a commercial substrate of pine bark for vegetables (Mecplant), for both experiments. The hybrid Magali R. was used, being sown only one seed per cell.

The preparation of the seedbeds began with the tillage of the experimental area with a rotary hoe. After this process, 28 seedbeds were built, $3 \mathrm{~m}$ long and $0.5 \mathrm{~m}$ wide. The seedlings were transplanted to the seedbeds 
when they had between four or six fully expanded leaves. Six plants were transplanted per seedbed with a spacing of 1.0 and $0.5 \mathrm{~m}$ between seedbeds and plants, respectively.

In the summer season, liming and fertilization were performed at 60 and 20 days before transplantation, respectively. Based on the soil analysis, $110 \mathrm{~kg} \mathrm{ha}^{-1}$ urea, $265 \mathrm{~kg} \mathrm{ha}{ }^{-1}, \mathrm{KCl}, 1.110 \mathrm{~kg} \mathrm{ha}{ }^{-1}$ single superphosphate, and $3 \mathrm{~kg}$ organic matter per plot were applied. In the winter-spring season, based on the soil analysis, $110 \mathrm{~kg} \mathrm{ha}^{-1}$ urea, $34 \mathrm{~kg} \mathrm{ha}^{-1}, \mathrm{KCl}, 220 \mathrm{~kg} \mathrm{ha}^{-1}$ simple superphosphate, and $3 \mathrm{~kg}$ organic material per plot were applied.

The doses of nutrients were based on the recommendation of Lorenzoni et al. (2016). Every fifteen days, fertirrigations were carried out with calcium nitrate and potassium chloride, according to the recommendation of Lorenzoni et al. (2016) and split according to the crop nutrient uptake rate (Fontes et al., 2005).

A drip micro-irrigation system was installed in the experimental area, with a uniformity coefficient of 96\%, classified as excellent (Frizzone et al., 2012). Each seedbed had a polyethylene lateral line $(16 \mathrm{~mm}$ diameter) with 12 self-compensating emitters $\left(4 \mathrm{~L} \mathrm{~h}^{-1}\right.$ flow) spaced every $25 \mathrm{~cm}$. The water was pumped by a centrifugal pump $(0.5 \mathrm{hp})$ connected to the two reservoirs. A reservoir (500L) was used to store water without magnetic treatment, and the other reservoir (1000L) was used to store the water with magnetic treatment.

Magnetic water treatment was performed using a Sylocimol Residence magnetizer (Timol Industry and Trade of Magnetic Products), composed of alternating magnets protected by a stainless steel cylinder, $(0.1 \mathrm{~m}$ of diameter and $0.165 \mathrm{~m}$ high) with a magnetic field of 1000 Gauss, assessed using a gaussmeter (LakeShore 425 Gaussmeter).

According to the manufacturer, the equipment is capable of magnetically treating $1000 \mathrm{~L}$ of water per hour. For standardization, and according to information, the magnet remained in the center of the water reservoir (1000 L) for one day (24 hours), enough time to guarantee the magnetic treatment of the water.

The treatments consisted of opening the reservoir shutoff valve containing magnetically-treated water for circulation through the system for 2 minutes of filling the entire pipe with treated water. After this process, the shutoff valve of the experimental plots irrigated with magnetically treated water was opened, remaining open according to the corresponding irrigation time of each treatment. At the end of irrigation with treated water, the process was repeated with water without magnetic treatment to irrigate the remaining plots.

Irrigation management was carried out based on climate and crop evapotranspiration values. The reference evapotranspiration (ETo) was estimated by the Penman-Monteith methodology (Allen et al., 1998), and the data of the meteorological variables were obtained in the automatic climate station installed inside the protected environment. Crop evapotranspiration (ETc) was determined by multiplying the ETo value by the crop coefficient $(\mathrm{Kc})$ of each crop phase: 0.6 (initial phase); 1.05 (intermediate phase) and 0.9 (final phase) (Allen et al., 1998). Knowing the application intensity (Ia) in each plot ( $\mathrm{mm}$ per min), the ETc value was divided by Ia, resulting in the irrigation time for each water depth based on ETc $(50 \%, 75 \%$, and $100 \%)$.

For the evaluations, the four central plants were used, being the ends considered as the border. The development variables analyzed during the summer, and winter-spring seasons were, first flower (FFL) and first fruit (FFR). The plants were checked daily, and the day when the first flower and the first fruit appeared in each plant was recorded.

Growth evaluation was performed at the end of each experiment (at 120 DAT for the summer and 150 DAT for the winter-spring). The plants were cut close to the soil surface, identified, and taken to the Centro Técnico de Irrigação Laboratory.

Table 1. Results of soil chemical analysis of macro and micronutrients of the experimental area*

\begin{tabular}{|c|c|c|c|c|c|c|c|}
\hline \multirow{2}{*}{ Season } & \multicolumn{2}{|c|}{$\mathrm{pH}$} & O.M. & $\mathrm{C}$ & $\mathrm{P}$ & $\mathrm{K}^{+}$ & $\mathrm{Ca}^{+2}$ \\
\hline & $\mathrm{CaCl}_{2}$ & $\mathrm{H}_{2} \mathrm{O}$ & \multicolumn{2}{|c|}{$\mathrm{g} \mathrm{dm}^{-3}$} & $\mathrm{mg} \mathrm{dm}^{-3}$ & \multicolumn{2}{|c|}{ cmolc dm ${ }^{-3}$} \\
\hline Summer & 4.50 & 5.00 & 9.86 & 5.72 & 2.82 & 0.08 & 1.11 \\
\hline Winter-spring & 6.50 & 7.30 & 10.35 & 6.00 & 36.61 & 0.72 & 4.99 \\
\hline \multirow{2}{*}{ Season } & $\mathrm{Mg}^{+2}$ & $\mathrm{Al}^{+3}$ & $\mathrm{H}^{+}+\mathrm{Al}^{+3}$ & SB & CTC & $\mathrm{V}$ & $\mathrm{S}$ \\
\hline & & & $\mathrm{cmol}_{\mathrm{c}} \mathrm{dm}^{-3}$ & & & $\%$ & $\mathrm{mg} \mathrm{dm}^{-3}$ \\
\hline Summer & 1.05 & 0.45 & 4.78 & 2.24 & 7.02 & 31.92 & 2.52 \\
\hline Winter-spring & 1.03 & 0.00 & 2.27 & 6.74 & 9.01 & 74.82 & $* * *$ \\
\hline \multirow{2}{*}{ Season } & $\mathrm{Cu}$ & $\mathrm{Zn}$ & $\mathrm{Fe}$ & $\mathrm{Mn}$ & $\mathrm{Na}^{+}$ & \multicolumn{2}{|c|}{$\mathrm{B}$} \\
\hline & \multicolumn{5}{|c|}{$\mathrm{mg} \mathrm{dm} \mathrm{m}^{-3}$} & & \\
\hline Summer & 12.26 & 3.15 & 153.1 & 39.78 & 9.35 & \multicolumn{2}{|c|}{0.05} \\
\hline Winter-spring & 7.71 & 2.53 & 66.48 & 47.91 & 31.32 & \multicolumn{2}{|c|}{$* * *$} \\
\hline
\end{tabular}

* Soil chemical analysis carried out at the Laboratório Rural de Maringá. Maringá, PR. 
Plant height, stem diameter, and leaf area were evaluated only in the summer season. These variables were not analyzed in the winter-spring season due to non-significance in the summer season with the application of magnetically treated water.

For the evaluation of plant height $(\mathrm{cm})$, the distance between the cut-off point and the apical meristem was measured. Stem diameter (mm) was measured about two centimeters above the cut-off point with the aid of a digital caliper. Leaf Area $\left(\mathrm{cm}^{2}\right.$ plant $\left.^{-1}\right)$ was measured using an LI-3100C Area Meter (LI-COR ${ }^{\circledR}$ Biosciences).

The dry matter of stem, leaf, root, and total (g plant1) were evaluated at the end of both cultivation seasons. For this, the plants were separated in leaf and stem and then placed in identified paper bags and put to dry in a forced-air oven at $65^{\circ} \mathrm{C}$ until constant mass. After drying, they were weighed on a precision scale $(0.01 \mathrm{~g})$. For dry root mass $\left(\mathrm{g} \mathrm{plant}^{-1}\right)$, the roots were taken with a steel plate sampler $(20 \mathrm{~cm}$ wide, $25 \mathrm{~cm}$ long and $30 \mathrm{~cm}$ deep) leveled into the ground. After removal, the roots were washed and left in the sun to dry and then placed in identified paper bags and taken to dry in a forced-air oven at $65^{\circ} \mathrm{C}$, until they have a constant mass. They were then weighed on a precision scale $(0.01 \mathrm{~g})$.

Data were submitted to analysis of variance, and the means were compared by the Tukey test, both at the $5 \%$ probability level. The analyzes were performed using Sisvar software (Ferreira, 2014).

\section{Results and Discussion}

The summer and winter-spring seasons had average temperatures ranging from 20.3 to $32.3^{\circ} \mathrm{C}$ and from 12.1 to $29.4{ }^{\circ} \mathrm{C}$, respectively. According to Filgueira (2012), for satisfactory production, temperatures should vary on average, between 19 and $21^{\circ} \mathrm{C}$ (Figure 1).
During the conduction of both experiments, were recorded temperatures above and below the values considered favorable to bell pepper development. However, no damage to the crop was observed as they were not constant throughout the seasons, occurring in short periods during the day or night.

According to the analysis of variance (Table 2), there was no significant interaction between the water depths and the application of treated water for the variables: plant height, stem diameter, and leaf area evaluated in the summer season. There was an isolated effect of the application of water depths on the three variables.

The data demonstrated that the water depth of $100 \%$ ETc was higher than the other water depths, with a value of $142.3 \mathrm{~cm}$ of height, $19.4 \mathrm{~mm}$ of stem diameter, and $10,770.6 \mathrm{~m}^{2}$ of leaf area, which are around $39.6 \%, 44.7 \%$, and $171.5 \%$ higher than the $75 \%$ ETc, and $65.2 \%, 84.7 \%$ and $323.4 \%$ higher than the $50 \%$ ETc for plant height stem diameter, and leaf area, respectively.

The results obtained in this study were different from those obtained by Yusuf and Ogunlela (2015) and Mohamed (2013) in tomato plants, who have found significant results, with higher growth of bell pepper when irrigated with magnetically-treated water.

It is possible to verify that water deficiency caused restrictions on plant growth. The cultivation of bell pepper under water stress conditions resulted in lower height, stem diameter, and leaf area than the water depth of $100 \%$ ETc.

Similar to the results of PH, SD, and LA variables, there was an isolated effect of the application of water depths to the development variables (first flower and first fruit) and growth (dry matter of stem, leaf, root, and total) evaluated in the summer season (Table 3).

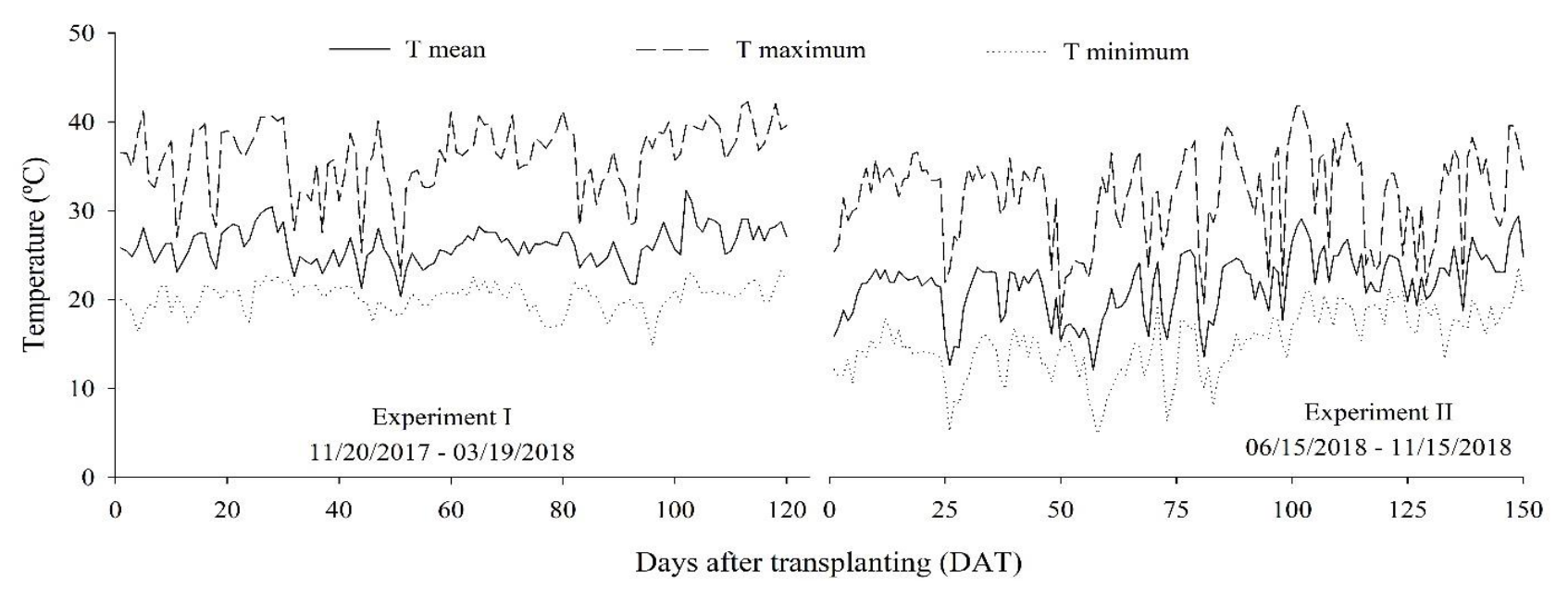

Figure 1. Maximum, mean, and minimum temperatures recorded daily within the protected environment during both experimental periods. 
Table 2. Summary of analysis of variance for plant height (PH), stem diameter (SD) and leaf area (LA), collected during the summer for bell pepper crop irrigated with water with and without magnetic treatment and irrigation depths of 50, 75 and $100 \%$ of ETc

\begin{tabular}{cccccc}
\hline \multirow{2}{*}{ Variable } & \multicolumn{3}{c}{ FV $(\%)$} & General average \\
\cline { 2 - 5 } & Water Treat. (WT) & Water Depths (WD) & WT x WD & & 110.46 \\
PH & $0.33^{\text {ns }}$ & $51.71^{*}$ & $0.37^{\text {ns }}$ & 10.34 & 14.46 \\
SD & $0.28^{\text {ns }}$ & $53.71^{*}$ & $0.20^{\text {ns }}$ & 12.01 & 5760.2 \\
LA & $0.00^{\text {ns }}$ & $133.42^{*}$ & $0.38^{\text {ns }}$ & 18.69 & 59 \\
\hline
\end{tabular}

* Significant at $5 \%$ probability by the $\mathrm{F}$ test, ${ }^{\mathrm{ns}}$ not significant by the $\mathrm{F}$ test.

Table 3. Summary of analysis of variance for development and growth variables collected during the summer for bell pepper crop irrigated with water with and without magnetic treatment and irrigation depths of 50, 75, and $100 \%$ of ETc.

\begin{tabular}{cccccc}
\hline \multirow{2}{*}{ Variable } & \multicolumn{3}{c}{ F values } & CV $(\%)$ & General average \\
\cline { 2 - 4 } & Water Treat. (WT) & Water Depths (WD) & WT x WD & & \\
\hline FFL & $2.02^{\text {ns }}$ & $5.50^{*}$ & $1.25^{\text {ns }}$ & 9.13 & 33 \\
FFR & $0.34^{\text {ns }}$ & $22.08^{*}$ & $1.50^{\text {ns }}$ & 7.77 & 53 \\
SDM & $0.84^{\text {ns }}$ & $55.98^{*}$ & $2.86^{\text {ns }}$ & 17.44 & 68.82 \\
LDM & $1.08^{\text {ns }}$ & $138.75^{*}$ & $0.24^{\text {ns }}$ & 15.20 & 32.90 \\
TDM & $1.12^{\text {ns }}$ & $94.47^{*}$ & $2.16^{\text {ns }}$ & 15.02 & 101.74 \\
RDM & $0.00^{\text {ns }}$ & $15.41^{*}$ & $0.25^{\text {ns }}$ & 21.24 & 38.40 \\
\hline
\end{tabular}

* Significant at $5 \%$ probability by the $\mathrm{F}$ test, ${ }^{\mathrm{ns}}$ not significant by the $\mathrm{F}$ test.

Souza et al. (2019) verified that the magnetic treatment of the irrigation water did not influence the growth of the eggplant plants cultivated in a protected environment and with water depths. According to the authors, the water depth with $100 \%$ of replacement provided higher values of the variables, regardless of water treatment.

According to Seron et al. (2019), the magneticallytreated water favored the development of scarlet eggplant, reducing the time for flowering and fruiting in the winter-spring season. However, for the plant height, stem diameter, and shoot dry matter, only the water replacement depth of $100 \%$ ETc obtained significant values.

The results of the variables presented in Table 3, were higher with higher irrigation level (100\% ETc). The first flower and the first fruit appeared at 30 and 47 DAT, respectively, for water replacement of $100 \%$ ETc. For the water replacement of $50 \% \mathrm{ETc}$, the first flower and the first fruit appeared at 35 and 60 DAT.

The highest SDM, LDM, and TDM were observed for water replacement depth of $100 \%$ ETc than the other water replacement depths (Figure 2). For the RDM variable, there was no significant difference between the water replacement depths of 75 and 100\% ETc, however, when compared to the water replacement depth of $50 \%$ ETc, a significant difference was found. In an experiment conducted by Souza et al. (2019), eggplant plants cultivated with $100 \%$ ETc had a higher accumulation of stem and leaf dry matter, similar to the results found in the present study.

According to Taiz et al. (2017), plant growth is related to cell division and expansion; water is a fundamental component of this process. Therefore, the high availability of water in crops promotes an increase in growth variables and biomass accumulation. This can be verified by applying the largest depth.

The application of the higher irrigation depth provided an increase in production per plant. Similar results can be found in studies by Santos et al. (2018), Lima et al. (2012) and Carvalho et al. (2011) for the bell pepper.

For the development variables (first flower and first fruit) and growth (dry matter of stem, leaf, root, and total) evaluated during the winter-spring season, there was a significant interaction between irrigation depths and water treatment only for the variables SDM, RDM, and TDM (Table 4). For the variables, FFL, FFR, and LDM, no significant differences were found.

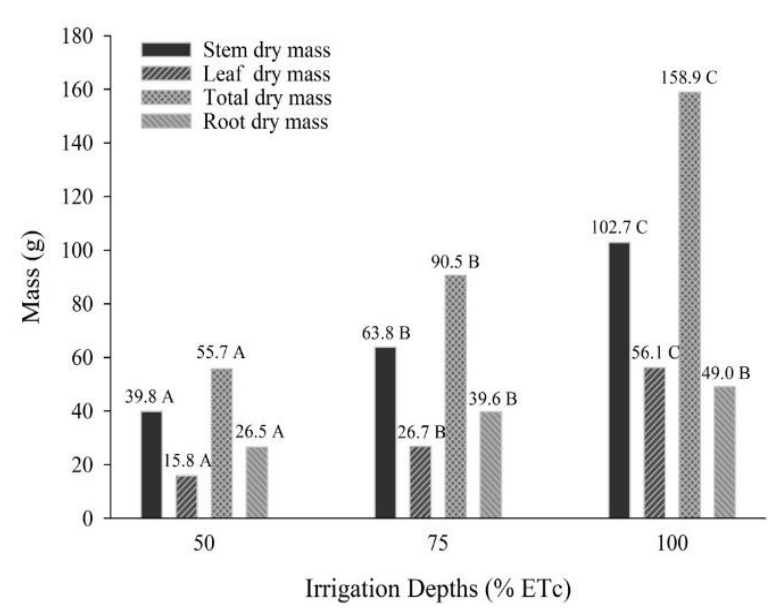

Figure 2. Stem dry matter (SDM), leaf dry matter (LDM), total dry matter (TDM), and root dry matter (RDM) for bell pepper cultivation irrigated with water with and without magnetic treatment and irrigation depths of 50, 75, and $100 \%$ of ETc. Different letters indicate a significant difference by Tukey test at $5 \%$ probability. 
Table 4. Summary of analysis of variance for development and growth variables, collected during the winter-spring season, for bell pepper cultivation irrigated with water with and without magnetic treatment and irrigation depths of 75 and $100 \%$ of ETc.

\begin{tabular}{cccccc}
\hline Variable & \multicolumn{3}{c}{ F values } & \multirow{2}{*}{ CV $(\%)$} & General average \\
\cline { 2 - 4 } & Water Treat. (WT) & Water Depths (WD) & WT x WD & & \\
\hline FFL & $0.04^{\mathrm{ns}}$ & $0.08^{\mathrm{ns}}$ & $0.18^{\mathrm{ns}}$ & 3.63 & 47 \\
FFR & $0.22^{\mathrm{ns}}$ & $1.31^{\mathrm{ns}}$ & $0.02^{\mathrm{ns}}$ & 3.61 & 56 \\
SDM & $0.51^{\mathrm{ns}}$ & $6.59^{*}$ & $7.59^{*}$ & 15.18 & 87.10 \\
LDM & $0.25^{\mathrm{ns}}$ & $3.69^{\mathrm{ns}}$ & $2.19^{\mathrm{ns}}$ & 24.75 & 42.46 \\
TDM & $0.64^{\mathrm{ns}}$ & $8.65^{*}$ & $7.98^{*}$ & 14.20 & 129.56 \\
RDM & $0.65^{\mathrm{ns}}$ & $0.00^{\mathrm{ns}}$ & $4.63^{*}$ & 13.26 & 25.61 \\
\hline
\end{tabular}

* Significant at $5 \%$ probability by the $\mathrm{F}$ test, ${ }^{\mathrm{ns}}$ not significant by the $\mathrm{F}$ test.

About the interaction of water treatment factors and irrigation depths, significant differences were observed in the application of magnetically-treated water in the water replacement depth of $75 \%$ ETc for the variables SDM, TDM, and RDM (Figure 3A, 3C, and 3E). In the water replacement depth of $75 \% \mathrm{ETc}$, the use of water with magnetic treatment resulted in SDM, TDM, and RDM around $26.4 \%, 26.0 \%$, and $17.4 \%$ higher than the use of water without magnetic treatment.

Yusuf and Ogunlela (2017) used the same amount of water with and without magnetic treatment to irrigate the tomato crop. They observed faster growth and easier absorption of water from the soil when irrigated with magnetically-treated water.

Hozayn et al. (2016) found a significant increase in all growth parameters (plant height, fresh and dry mass of the plant) in canola plants when irrigated with magnetically-treated water. Sayed (2014) observed a significant increase in growth parameters (plant height, dry matter of leaves, stem, and root and leaf area) with
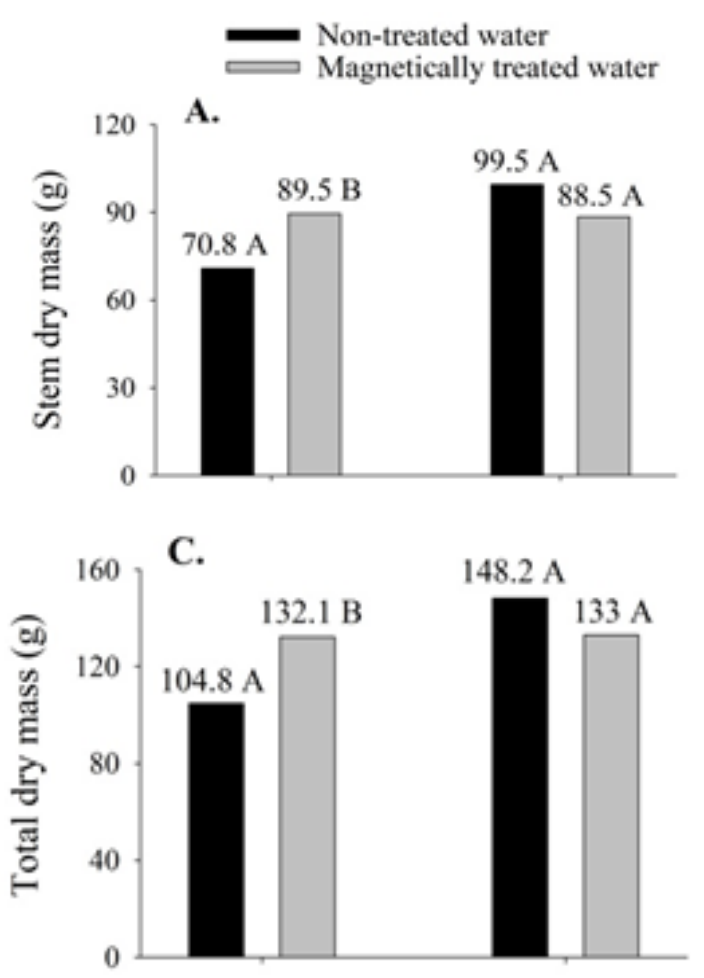

the application water with magnetic treatment when compared to the application of water without magnetic treatment in bean crop.

Surendran et al. (2016) found significant differences in plant height, leaf number, and leaf area with the application of magnetically-treated water to eggplant crop. Putti et al. (2013) investigating the benefits of magnetically-treated water for irrigation in the initial development of lettuce in Botucatu-SP, they verified a significant increase in root length, fresh and dry matter of roots and shoot of lettuce irrigated with treated water.

The results verified in the mentioned studies corroborate with Ospina-Salazar et al. (2018), who concluded that not all plants respond significantly when irrigated with magnetically-treated water.

About the water without magnetic treatment, the application of water replacement depth of $100 \%$ ETc had higher SDM (Figure 3B) and TDM (Figure 3D) than the water replacement depth of $75 \%$ ETc.

B.
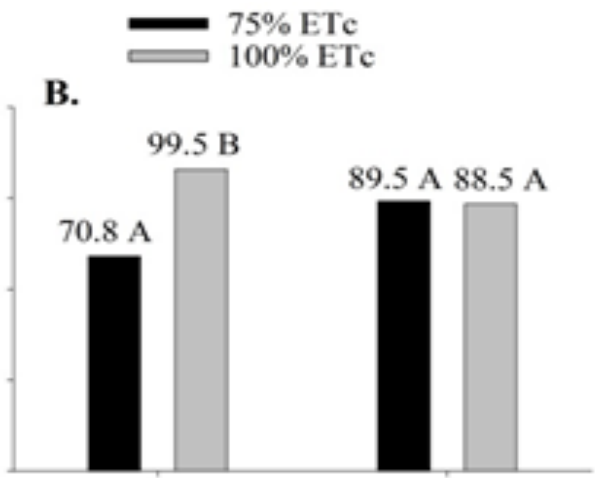

D.

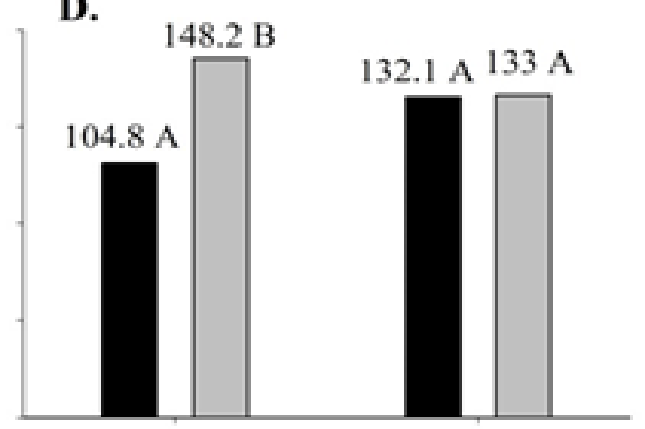



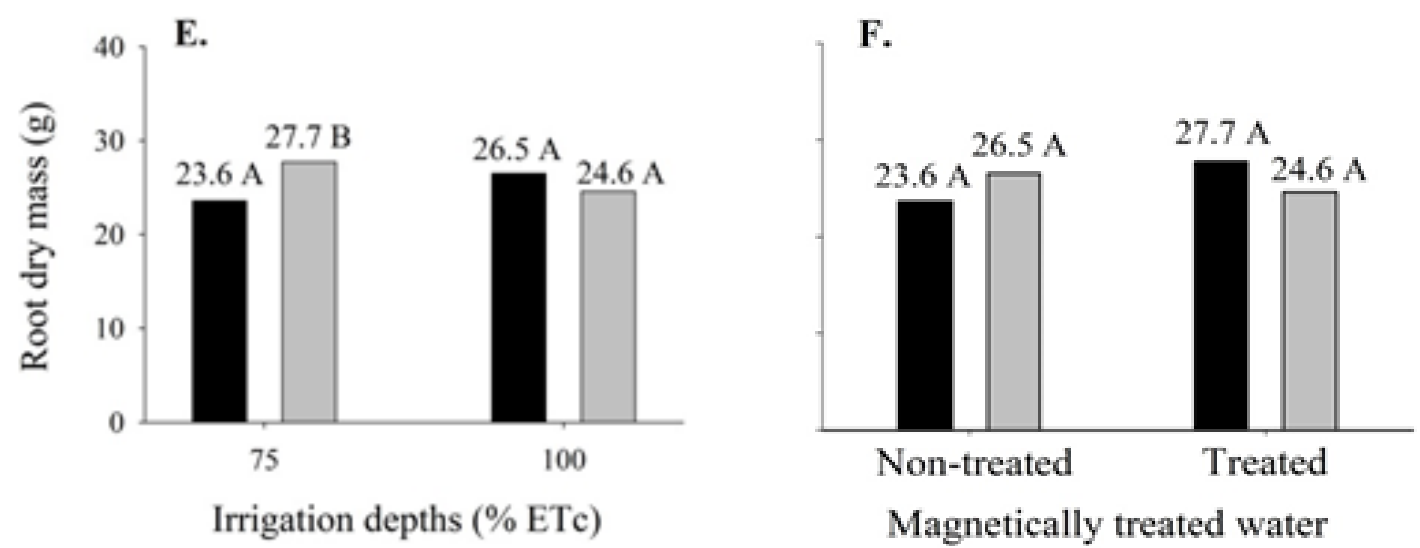

Figure 3. Interaction between the factors for stem dry matter (SDM), total dry matter (TDM), and root dry matter (RDM) for the cultivation of pepper irrigated with water with and without magnetic treatment and irrigation depths of 75 and $100 \%$ ETc. Different letters indicate a significant difference by Tukey test at $5 \%$ probability.

The significant differences found with the application of magnetically-treated water only in the winter-spring season may be related to the temperature conditions that occurred during this period. Whereas periods of low temperatures lead to a decrease in plant development and consequently increase the cultivation cycle (Filgueira, 2012), the bell pepper plants were exposed for a longer time to irrigation with magnetically-treated water, which may have favored the significant responses with the application of the water replacement depth of $75 \%$ ETc, which probably causes less evaporation and percolation loss when compared to the $100 \%$ ETc.

Constant use of magnetically-treated water can increase nutrient absorption and biomass production in different crops (Mahmood and Usman, 2014; Maheshwari and Grewal, 2009). According to Sayed (2014), studies involving the application of magnetically-treated water in agriculture involves a series of experimental conditions, such as exposure time and magnetic field intensity.

\section{Conclusions}

The magnetically-treated water did not influence the growth and development of the bell pepper plants.

Water replacement depth of $100 \%$ ETc promoted higher values for growth and development variables for a 120-day cycle, regardless of water treatment.

For a 150-day cycle, the application of water with the magnetic treatment provided greater accumulation of dry matter (stem, total, and root) when irrigated with $75 \%$ ETc.

\section{Bibliographic References}

Ali, Y., Samaneh, R., Kavakebian, F., 2014. Applications of magnetic water technology in farming and agriculture development: A review of recent advances. Current World Environment, 9(3), 695-703.

Allen, R.G., Pereira, L.S., Raes, D., Smith, M., 1998. Crop Evapotranspiration: guidelines for computing crop water requirements. Rome: FAO.

Alvares, C.A., Stape, J.L., Sentelhas, P.C., Gonçalves, J.L.M., Sparovek, G., 2013. Köppen's climate classifcation map for Brazil. Meteorologische Zeitschrift, 22(6), 711-728.

Carvalho, J.A., Rezende, F.C., Aquino, R.F., Freitas, W.A., Oliveira, E.C., 2011. Análise produtiva e econômica do pimentão-vermelho irrigado com diferentes lâminas, cultivado em ambiente protegido. Revista Brasileira de Engenharia Agrícola e Ambiental, 15(6), 569-574.

EMBRAPA. Empresa Brasileira de Pesquisa Agropecuária, 2013. Centro Nacional de Pesquisa de Solos. Sistema brasileiro de classificação de solos, terceira ed. Rio de Janeiro, Embrapa, 353 p.

Ferreira, D.F., 2014. Sisvar: a Guide for its Bootstrap procedures in multiple comparisons. Ciência e Agrotecnologia, 38(2), 109-112.

Filgueira, F.A.R., 2012. Novo manual de olericultura: Agrotecnologia moderna na produção e comercialização de hortaliças, terceira ed. Viçosa, Editora UFV.

Fontes, P.C.R., Dias, E.N., Graça, R.N., 2005. Acúmulo de nutrientes e método para estimar doses de nitrogênio e potássio na fertirrigação do pimentão. Horticultura Brasileira, 23(2), 275-280

Frizzone, J.A., Freitas, P.S.L., Rezende, R., Faria, M.A., 2012. Microirrigação: gotejamento e microaspersão. Maringá, Eduem.

Hozayn, M., Abdallha, M.M., Abd El-Monem, A.A., ElSaady, A.A., Darwish, M.A., 2016. Applications of magnetic technology in agriculture: A novel tool for improving crop productivity (1): Canola. African Journal of Agricultural Research, 11(5), 441-449.

Lima, E.M.C., Matiolli, W., Thebaldi, M.S., Rezende, F.C., Faria, M.A., 2012. Produção de pimentão cultivado em 
ambiente protegido e submetido a diferentes lâminas de irrigação. Revista Agrotecnologia, 3(1), 40-56.

Lorenzoni, M.Z., Rezende, R., Souza, A.H.C., Seron, C.C., Hachmann, T.L., Freitas, P.S.L., 2016. Response od bell pepper crop fertigated with nitrogen and potassium doses in protected environment. Agrotechnology, 5(3), 148-152.

Maheshwari, B.L., Grewal, H.S., 2009. Magnetic treatment of irrigation water: Its effects on vegetable crop yield and water productivity. Agricultural Water Management, 96(8), 12291236.

Mahmood, S., Usman, M., 2014. Consequences of magnetized water application maize seed emergence in sand culture. Journal of Agricultural Science and Technology, 16(1), 47-55.

Mohamed, A.I., 2013. Effects of magnetized low quality water on some soil properties and plant growth. International Journal of Research in Chemistry and Enviroment, 3(2), 140-147.

Ospina-Salazar, D.I., Benavides-Bolaños, J.A., ZúñigaEscobar, O., Muñoz-Perea, C.G., 2018. Photosynthesis and biomass yield in Tabasco pepper, radish and maize subjected to magnetically treated water. Corpoica Ciencia y Tecnologia Agropecuaria, 19(2), 307-321.

Putti, F.F., Gabriel Filho, L.R.A., Klar, A.E., Cremasco, C.P., Ludwig, R., Silva Junior, J.F., 2013. Desenvolvimento inicial da alface (Lactuca sativa L.) irrigada com água magnetizada. Cultivando o Saber, 6(3), 83-90.

Santos, E.S., Silva, Ê.F.F., Montenegro, A.A.A., Souza, E.S., Souza, R.M.S., Silva, J.R.I., 2018. Produtividade do pimentão sob diferentes lâminas de irrigação e doses de potássio em região semiárida. Irriga, 23(3), 518-534.
Sayed, H.E.S.A.E., 2014. Impact of magnetic water irrigation for improve the growth, chemical composition and yield production of Broad Bean (Vicia faba L.) plant. American Journal of Experimental Agriculture, 4(4), 476-496.

Seron, C.C., Rezende, R., Lorenzoni, M.Z., Souza, A.H.C., Gonçalves, A.C.A., Saath, R., 2019. Irrigation with water deficit applying magnetic water on scarlet eggplant. Revista de Agricultura Neotropical, 6(4), 21-28.

Soil Survey Staff, 2014. Keys to Soil Taxonomy, 12th ed. Washington, DC: USDA-Natural Resources Conservation Service, Washington, DC.

Souza, A.H.C., Rezende, R., Seron, C.C., Lorenzoni, M.Z., Nascimento, J.M.R., Lozano, C.S., Nalin, D., Terassi, D.S., Gonçalves, A.C.A., Saath, R., Freitas, P.S.L., 2019. Evaluation of the growth and the yield of Eggplant crop under different irrigation depths and magnetic treatment of water. Journal of Agricultural Science, 11(17), 35-43.

Surendran, U., Sandeep, O., Joseph, E.J., 2016. The impacts of magnetic treatment of irrigation water on plant, water and soil characteristics. Agricultural Water Manegement, 178, 21-29.

Taiz, L., Zeiger, E., Moller, I.M., Murphy, A., 2017. Fisiologia e desenvolvimento vegetal, sexta ed. Porto Alegre, Artmed.

Yusuf, K.O., Ogunlela, A.O., 2017. Effect magnetic treatment of water on evapotranspiration of tomato. Arid Zone Journal of Engineering, Technology and Environment, 13(1), 86-96.

Yusuf, K.O., Ogunlela, A.O., 2015. Impact of magnetic treatment of irrigation water on the growth and yield of tomato. Notulae Scientia Biologicae, 7(3), 345-348. 